\title{
PREVALENCE AND DETERMINANTS OF STUNTING AMONG CHILDREN UNDER TWO YEARS OF AGE IN KUPANG, EAST NUSA TENGGARA
}

\author{
Nabilah Nurul Ilma'), Harsono Salimo²), Eti Poncorini Pamungkasari2) \\ 1)Masters Program in Public Health, Universitas Sebelas Maret \\ ${ }^{2)}$ Faculty of Medicine, Universitas Sebelas Maret
}

\begin{abstract}
Background: Globally in 2017, 155 million children under 5 were estimated to be stunted. Stunting is a well-established risk marker of poor child development. Identifying determinants of stunting among children under five would help to set priorities for action and to the design of stunting reduction plan. This study aimed to determine prevalence and determinants of stunting among children under two years of age in Kupang, East Nusa Tenggara.

Subjects and Method: This was a case control study conducted at 25 integrated health posts in Alak and Oebobo Subdistricts, in Kupang, East Nusa Tenggara, from November to December 2018. A sample of 200 children under two years was selected by multi-stage random sampling. The dependent variable was stunting. The independent variables were diarrhea, birth length, parental income, maternal education, exclusive breastfeeding, maternal height, maternal mid-upper arm circumference (MUAC), complementary feeding, maternal hygiene practice, and sanitation. The data were collected by questionnaire and analyzed by a multiple logistic regression.

Results: Stunting prevalence in Kupang was 30.5\%. The risk of stunting decreased with appropriate complementary feeding $(\mathrm{b}=-1.97 ; 95 \% \mathrm{CI}=-3.55$ to $-0.39 ; \mathrm{p}=0.014)$, good hygiene practice $(b=-4.38 ; 95 \% C I=-6.63$ to $-2.12 ; p<0.001)$, good sanitation $(b=-2.32$; $95 \% \mathrm{CI}=-4.00$ to $-0.64 ; \mathrm{p}=0.007)$, and birth length $\geq 48 \mathrm{~cm}(\mathrm{~b}=-2.22 ; 95 \% \mathrm{CI}=-3.74$ to $-0.69 ; \mathrm{p}=0.004)$. The risk of stunting increased with recurrence diarrhea $(b=2.55 ; 95 \%$ $\mathrm{CI}=1.01$ to $4.09 ; \mathrm{p}=0.001$ ).

Conclusion: The risk of stunting decreases with appropriate complementary feeding, good hygiene practice, good sanitation, and birth length $\geq 48 \mathrm{~cm}$. The risk of stunting increases with recurrence diarrhea.
\end{abstract}

Keywords: stunting, determinants

Correspondence:

Nabilah Nurul Ilma Masters Program in Public Health, Universitas Sebelas Maret, Jl. Ir. Sutami 36 A, Surakarta 57126, Central Java. Email: nabilahnurul86@gmail.com.

Mobile: +6287838555468 .

The 5th International Conference on Public Health Best Western Premier Hotel, Solo, Indonesia, February 13-14, 2019 | 270 https://doi.org/10.26911/theicph.2019.03.22 